\title{
24 The use of digital devices in the classroom
}

\author{
Tracii Ryan, Michael Henderson, and \\ Jesper Aagaard
}

\section{How to use this policy}

The use of digital devices in the classroom can have various benefits for students. However, when used at inopportune times or in inappropriate ways, devices may be counterproductive to learning. As digital devices are now an integral part of life, it is critical that students develop the skills needed to responsibly manage the use of these tools. This policy highlights how schools can harness the potential learning benefits of digital devices in the classroom, while also supporting students to responsibly self-regulate their usage. This policy example is intentionally broad and school policy creators are encouraged to delete and build upon suggestions below to create a policy that best represents their school.

[To adapt and use this policy, delete or modify the text as indicated]

\section{[INSERT name of school] The use of digital devices in the classroom}

\section{Rationale}

The introduction of digital devices into the classroom can have various benefits for students, such as improving organisation, engagement and collaboration (Zheng, Warschauer, Lin \& Chang, 2016). When appropriately built into the curriculum, device use may also foster 21 st-century and digital citizenship skills (Hollandsworth, Dowdy \& Donovan, 2011; Kaufman, 2013). However, certain types of device use may also reduce student wellbeing and learning. For example, students may post risky or inappropriate content online (de Zwart, Lindsay, Henderson \& Phillips, 2011) or use social media to ostracise or bully their peers (Allen, Ryan, Gray, McInerney \& Waters, 2014). Devices in the classroom may also be distracting, particularly when students use them for off-task activities (Aagaard, 2015). This behaviour is known to reduce attention (Risko, Buchanan, Medimorec \& Kingstone, 2013), knowledge retention (Flanigan \& Babchuk, 2015) and academic performance (Junco \& Cotten, 2012). While some schools have responded to these challenges by banning the use of digital devices (Selwyn, 2019), such 
responses avoid the issues rather than resolving them (Elliott-Dorans, 2018). Instead, it is critical that the school community works together to ensure that there are clear expectations around appropriate device use and that these tools are embedded into the curriculum in productive and engaging ways.

\section{Purpose}

Digital devices are powerful educational tools when used appropriately but, under certain circumstances, they can also detract from learning. Banning the use of devices at school is one way to tackle the problem, but it does not help students learn how, when and why to effectively manage their use of digital devices for learning. The policy position offered here is one in which the school works together to maximize educational outcomes and wellbeing, and safely and responsibly supports students to self-regulate the appropriate use of their digital devices.

\section{Scope}

This policy covers student use of digital devices, software and online services in school-related settings. Students' safe, responsible and respectful use of digital devices and online services is the shared responsibility of students, parents, carers and school staff. Therefore, the development and enactment of this policy and related procedures should take into consideration the needs of the whole school community. This may require some reasonable adjustments and exemptions for individual students or specific teaching and learning contexts.

[INSERT specific roles and responsibilities of individuals or teams who have particular roles in managing digital device usage]

\section{Policy statement}

\section{Policy governance}

The following policy and related procedures implemented at [INSERT name of school] will be reviewed on a regular basis, in consultation with experts in the field, regulatory frameworks and the entire school community.

Parents, carers, and, if appropriate, students at [INSERT name of school] may request that the principal consider specific needs and approve individual adjustments and exemptions to the following policy (Evans, 2019).

[INSERT name of school] uses social contracts to ensure that all key stakeholders' expectations are aligned around the appropriate use of digital devices in the classroom, along with the consequences for misuse (Engel \& Green, 2011; Keengwe, Schnellert \& Jonas, 2014). 


\section{Digital citizenship}

[INSERT name of school] is a place where students are supported to develop the skills they need to be successful in the 21 st century, by using the digital devices they have access to and feel comfortable using in the classroom (Engel \& Green, 2011).

At [INSERT name of school], the use of digital devices in the classroom will occur in ways that add to the learning experience rather than detracting from it (Evans, 2019).

[INSERT name of school] will help students and teachers reject the myth of "digital natives" as adept multitaskers and raise awareness about the negative consequences of digital distraction (Kirschner \& De Bruyckere, 2017).

[INSERT name of school] will help students delay gratification from digital devices and teach them to self-regulate and design distraction-free work environments (Flanigan \& Kiewra, 2018).

\section{Student agency around digital device use}

[INSERT name of school] recognises that digital devices can be more distracting for some students (Parry, le Roux \& Cornelissen, 2019) and will work with each student to identify personalised approaches. Where appropriate, this may include options that do not use devices.

Students at [INSERT name of school] will be given the opportunity to contribute to the development of policy for the appropriate use of digital devices, as well as the consequences for misuse (Engel \& Green, 2011; Thomas \& Muñoz, 2016).

\section{Accessibility of digital devices and technology}

At [INSERT name of school], the integration of technology into learning activities occurs in fair and equitable ways for all students (Engel \& Green, 2011; Evans, 2019). Alternative activities and/or spare devices will be made available for student(s) where required.

[INSERT name of school] will have in place filtering systems that help manage, control and limit access to non-desirable sites or technology protocols. The entire school community will be involved in decision making about the kinds of sites and protocols that should be limited.

[INSERT name of school] will ensure that students have access to the services and facilities they need to use digital devices in the classroom, including internet bandwidth, power outlets, etc. (Evans, 2019; Selwyn, Nemorin, Bulfin \& Johnson, 2017).

\section{Adequate support and training for teachers and students}

Students at [INSERT name of school] will be provided with a list of applications, programs and websites that are approved for use in the classroom 
(Erickson-Guy \& Gullen, 2013) and will receive instructions and training about how to use digital devices effectively for learning (Ott, Magnusson, Weilenmann \& af Segerstad, 2018).

Teachers and students at [INSERT name of school] will have access to appropriate technical support (Thomas \& Muñoz, 2016).

Teachers and students at [INSERT name of school] will have a clear understanding of how digital devices work, any potential issues relating to safety and security, and the purpose and role of the device in their classroom (Engel \& Green, 2011).

[INSERT name of school] will provide teachers with professional development opportunities and encourage the formation of professional learning communities to build capacity and understandings around how to integrate digital devices into the curriculum (Ott et al., 2018; Thomas \& Muñoz, 2016).

\section{Appropriate usage of digital devices}

Students at [INSERT name of school] will not use digital devices inappropriately in the classroom. Inappropriate use involves using devices in ways that are not relevant to the learning activity (Erickson-Guy \& Gullen, 2013).

Students at [INSERT name of school] will use digital devices in a manner that does disturb or disrespect anyone, including teachers and peers (EricksonGuy \& Gullen, 2013; Ott et al., 2018). For example, audible noises from devices should be limited using mute features.

Digital devices that are allowed in the classroom at [INSERT name of school] must be kept visible at all times during use (Erickson-Guy \& Gullen, 2013). During designated device-free times, students must turn off, put away or hand over devices as directed by their teachers (Engel \& Green, 2011; Keengwe et al., 2014).

[INSERT name of school] will have processes in place for students, parents, carers and teachers to discuss any concerns around inappropriate or problematic use of digital devices.

\section{Managing misuse of digital devices}

The misuse of digital devices will be treated in the same way as other misconduct at [INSERT name of school]. School actions as a consequence of the misuse will be appropriate and proportionate as per school behaviour policy.

It is the responsibility of staff, students, volunteers and families at [INSERT name of school] to report incidents of inappropriate use of digital devices and online services in accordance with school procedure, departmental policy and any statutory and regulatory obligations to help prevent any further incidents and provide support where required.

Teachers at [INSERT name of school] will apply consequences for misuse of digital devices fairly and consistently (Engel \& Green, 2011; Ott et al., 2018). 


\section{Rating of evidence base}

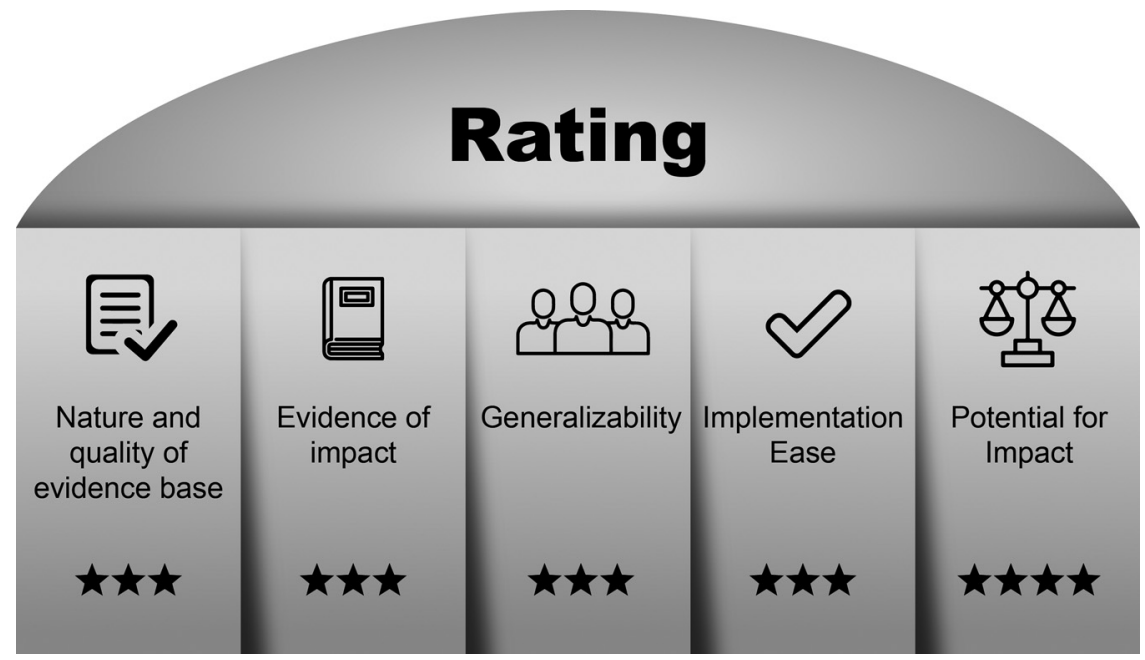

Figure 24.1. The Use of Digital Devices in the Classroom Rating of Evidence.

Author Note. There has been a substantial amount of well-designed empirical evidence supporting some aspects of this policy (e.g., digital distraction, supporting teachers), but other areas (e.g., student agency, digital citizenship) would benefit from further research. There is a need for additional longitudinal research to confirm the impact of the policy statements provided here. Further empirical research focused on secondary school contexts would improve generalisability of findings. In general, the policy could be implemented without extensive cost to schools. Minor to moderate expenditure may be required to ensure networks are adequate and all students have equitable access to digital devices. Digital devices are an integral part of personal and professional life, and teaching students how to self-regulate their use is not only an essential 21 st-century skill but could improve learning outcomes.

\section{Authorship}

Dr Tracii Ryan, The University of Melbourne

Professor Michael Henderson, Monash University

Dr Jesper Aagaard, Aarhus University

[INSERT RELEVANT STAFF MEMBERS]

\section{Related policy and documents}

[INSERT RELEVANT POLICY AND DOCUMENTS]

\section{Date of ratification}

This policy was ratified on the [INSERT DATE]. 


\section{Date of review}

This policy will be reviewed by [INSERT DATE].

\section{References}

Aagaard, J. (2015). Drawn to distraction: A qualitative study of off-task use of educational technology. Computers \& Education, 87, 90-97. doi:10.1016/j.compedu.2015.03.010

Allen, K., Ryan, T., Gray, D., McInerney, D., \& Waters, L. (2014). Social media use and social connectedness in adolescents: the positives and the potential pitfalls. The Australian Educational and Developmental Psychologist, 31(1), 18-31. doi:10.1017/ edp. 2014.2

de Zwart, M., Lindsay, D., Henderson, M., \& Phillips, M. (2011). Teenagers, legal risks and social networking sites. Monash University Faculty of Education. http:// newmediaresearch.educ.monash.edu.au/lnm/wp-content/uploads/2015/04/SNSa ndRisks_REPORT.pdf

Elliott-Dorans, L. (2018). To ban or not to ban? The effect of permissive versus restrictive laptop policies on student outcomes and teaching evaluations. Computers \& Education, 126, 183-200. doi:10.1016/j.compedu.2018.07.008

Engel, G., \& Green, T. (2011). Cell phones in the classroom: Are we dialing up disaster? TechTrends, 55(2), 39-45. doi:10.1007/s11528-011-0482-z

Erickson-Guy, N., \& Gullen, K. (2013). Beyond texting: Using cell phones in the classroom. Middle Ground, 16(4), 14. https://www.amle.org/portals/0/pdf/mg/apr2013.pdf

Evans, J. A. (2019). Digital learning: Peril or promise for our K-12 students (National briefing paper - Speak Up 2018/19). https://tomorrow.org/Speakup/downloads/ 2018_19-Speak-Up-National-Congressional-Briefing-Paper.pdf

Flanigan, A. E., \& Babchuk, W. A. (2015). Social media as academic quicksand: A phenomenological study of student experiences in and out of the classroom. Learning and Individual Differences, 44, 40-45. doi:10.1016/j.lindif.2015.11.003

Flanigan, A., \& Kiewra, K. (2018). What college instructors can do about student cyber-slacking. Educational Psychology Review, 30(2), 585-597. doi:10.1007/s10648017-9418-2

Hollandsworth, R., Dowdy, L., \& Donovan, J. (2011). Digital citizenship in K-12: It takes a village. TechTrends, 55(4), 37-47. doi:10.1007/s11528-011-0510-z

Junco, R., \& Cotten, S. R. (2012). No A 4 U: The relationship between multitasking and academic performance. Computers \& Education, 59(2), 505-514. doi:10.1016/j. compedu.2011.12.023

Kaufman, K. J. (2013). 21 ways to 21 st Century skills: Why students need them and ideas for practical implementation. Kappa Delta Pi Record, 49(2), 78-83. doi:10.1080/00228958.2013.786594

Keengwe, J., Schnellert, G., \& Jonas, D. (2014). Mobile phones in education: Challenges and opportunities for learning. Education and Information Technologies, 19(2), 441-450. doi:10.1007/s10639-012-9235-7

Kirschner, P., \& De Bruyckere, P. (2017). The myths of the digital native and the multitasker. Teaching and Teacher Education, 67, 135-142. doi:10.1016/j.tate.2017.06.001

Ott, T., Magnusson, A. G., Weilenmann, A., \& af Segerstad, Y. H. (2018). "It must not disturb, it's as simple as that": Students' voices on mobile phones in the infrastructure for learning in Swedish upper secondary school. Education and Information Technologies, 23(1), 517-536. doi:10.1007/s10639-017-9615-0 
182 Ryan, Henderson, \& Aagaard

Parry, D., le Roux, D., \& Cornelissen, L. (2019). Managing in-lecture media use: The feasibility and value of a split-class policy. Journal of Computing in Higher Education. Advance online publication. doi:10.1007/s12528-019-09232-z

Risko, E. F., Buchanan, D., Medimorec, S., \& Kingstone, A. (2013). Everyday attention: Mind wandering and computer use during lectures. Computers \& Education, 68, 275-283. doi:10.1016/j.compedu.2013.05.001

Selwyn, N. (2019, June 26). Banning mobile phones in schools: beneficial or risky? Here's what the evidence says. The Conversation. https://theconversation. com/banning-mobile-phones-in-schools-beneficial-or-risky-heres-what-the-evi dence-says-119456

Selwyn, N., Nemorin, S., Bulfin, S., \& Johnson, N. F. (2017). Left to their own devices: the everyday realities of one-to-one classrooms. Oxford Review of Education, 43(3), 289-310. doi:10.1080/03054985.2017.1305047

Thomas, K., \& Muñoz, M. A. (2016). Hold the phone! High school students' perceptions of mobile phone integration in the classroom. American Secondary Education, 44(3), 19-37. https://eric.ed.gov/?id=EJ1110299

Zheng, B., Warschauer, M., Lin, C. H., \& Chang, C. (2016). Learning in one-to-one laptop environments: A meta-analysis and research synthesis. Review of Educational Research, 86(4), 1052-1084. doi:10.3102/0034654316628645 